\title{
Assessment of Egg Quality and Quantity of Herotilapia multispinosa (Rainbow Cichlid) Fed with Two Different Protein/Fat Ratio Feeds
}

\section{Deniz D Tosun* and Emrah Kaya}

Faculty of Aquatic Sciences Aquaculture Department, Istanbul University, Turkey

*Corresponding Author: Deniz D Tosun, Faculty of Aquatic Sciences Aquaculture Department, Istanbul University, Turkey.

Received: June 04, 2018; Published: July 03, 2018

DOI: $10.31080 /$ ASNH.2018.02.0110

\begin{abstract}
In this study, adult rainbow cichlids were fed with two feeds with different protein/fat ratios. Both feeds were commercially available. The Aim of this study was to evaluate the effects of protein/fat ratios on the quality and quantity of eggs laid by the female fish. Amount of laid eggs and morphometric measurements were compared. Protein rich feeds resulted in more eggs laid by the females but the egg size was smaller compared to the group fed with a higher fat ratio feed. In terms of quantity of eggs for an aquarium fish producer, it can be advisable to use high protein feeds for broodstock rainbow cichlids for a greater number of larvae. But it should be kept in mind that eggs with bigger size may produce stronger and healthy larvae with lower mortality.
\end{abstract}

Keywords: Rainbow Cichlid; Fecundity; Protein; Egg Quality; Feeding

\section{Introduction}

Cichlid fish are popular aquarium fish in Turkey. They show family bonding like birds or mammals. Cichlid fish have 1330 species under Cichlidae family, they form the second biggest family in Perciformes [1]. This family of fish constitutes approximately $95 \%$ of aquarium fish around the world [2]. These fish are well known and sought for by the aquarium enthusiasts with their large scale of vibrant colors [3]. Reports show that there are 22 species of cichlids imported to Turkey. Thus, aquarium fish producers are actively in pursuit of better broodstock management practices to breed and supply this giant worldwide industry with a variety of cichlid fish $[4]$.

Rainbow Cichlid (Herotilapia multispinosa) belongs to the Cichlidae family [5]. They were taken from Cichlidisoma genus to Herotilapia genus in 1903 [6]. Rainbow cichlid is a Central American freshwater species which is easily kept in aquarium conditions. It has rainbow colors and a peaceful nature with manageable body sizes that lets the aquarist handle the fish easily in an aquarium. They prefer rocky areas to lay their eggs. Males have more vibrant colors compared to the females. Male fish are bigger in length and more colorful. They grow to be $10 \mathrm{~cm}$ average in length with a maximum of $15 \mathrm{~cm}$. Rainbow cichlid belongs to Cichlidae family $[7,8]$.
Although Body coloration changes during breeding, it is generally gold or orange. They are known to change color both morphologically and physiologically $[9,10]$. They protect their breeding grounds an eggs. These fish can be kept in tanks in high stocking ratios where they can breed [11].

Rainbow cichlids are omnivorous. In their natural habitat, they consume filamented algae, diatoms, zooplankton, insects, artemia, plants, eggs of the invertebrates, snails, leach and small fish suitable for their size [12]. In aquariums and production units, they are fed with artificial diets, tubifex worms, microworms, frozen worms and algae products $[13,14]$. They prefer to choose a long term mate for breeding and protect their nests which they locate at rocky areas. After mating, fish cleanse the area for egg laying and starts protection against other fish. Male fish takes responsibility for protection. Female lays the eggs which are sticky on a smooth surface. Laying eggs lasts for 2 hours and in a single batch female lays 500 - 1500 eggs depending on its age and size. In natural habitats the amount of eggs and their quality depends on the available nutrients fish gets from the ecosystem. Larval survival is directly related with egg quality. During incubation female uses its tail to refresh oxygenated water to the eggs. Eggs hatch after 2 days. Female carries the larvae to an oxygen rich and protected location. After four weeks of parental protection, larvae are let free [15]. 
They can be cultured artificially in small tanks for commercial or laboratory purposes.

Breeding takes place after the fish chooses their mate. Female chooses the location for laying the eggs and male gets ready for protection. Female lays the eggs which are sticky at smooth strata. It takes approximately 2 hours for the female to lay up to 1500 eggs in a single breeding period. Females use their caudal fin to fan the eggs with fresh and oxygen rich water. Eggs hatch after 2 days. Female carries the newly hatched larvae to a more protected area with enough oxygen and this lasts for 4 weeks after this period fry are free to roam on their own [15].

Aquarium fish trade is an important economic industry around the world. Production of economic and sought for species under controlled conditions is very important to provide aquarists the desired species. Controlled production depends on successful breeding practices. Better broodstock feeding requires adequate formulated feeds with engineered contents. In this study we compared the effects of two feeds with different protein/fat ratios on the egg quality and quantity of rainbow cichlids. Our aim is to identify better feeding strategies to generate more effective breeding operations for rainbow cichlid producers. Specific data about Herotilapia multispinosa breeding related with feeding strategies will give the producers a chance to optimize their production.

\section{Material and Methods}

Fish

Rainbow cichlid (Herotilapia multispinosa) used in this study were provided by the Aquarium Laboratory of Istanbul University, Faculty of Aquatic Sciences. Four couples of pre-mated female and male fish were selected for breeding. Fish couples were placed in separate glass aquaria. Females were at the same age $(2+)$. Female fish weighed $24 \pm 0,5 \mathrm{~g}$ with $10 \pm 0,5 \mathrm{~cm}$ body length where males weighed $12 \pm 1 \mathrm{~g}$ with $8 \pm 0,5 \mathrm{~cm}$ body lenght.

\section{Equipment}

Four Glass aquaria with $63 \mathrm{~L}$ capacity with heaters were used integrated in a recirculation filtration system to keep water parameters optimum for rainbow cichlid breeding.

\section{Experimental Design}

Experimental groups were designed as 2 X 2. Two experimental groups with 2 repetitions were used. Water temperature $(22 \pm$ 1oC), pH (7.5 - 7.6) and oxygen (6.7 $\pm 1 \mathrm{mg} / \mathrm{l})$ in the glass aquaria were kept constant in the recirculation system. Only difference was the feeds used with different protein/fat ratios.

\section{Feeds and Feeding Regime}

Each group received ad-libitum feeding 3 times a day. Two types of feed were used. Group 1 received low protein diet and Group 2 received high protein and higher fat content feed. Feeding lasted for 60 days.

Group 1 and 2 feeds consisted of fish meal, wheat meal, shrimp meal, fish oil, astaxanthin, spirulina with $37 \%$ crude protein, $3 \%$ crude lipids for Group 1 and with 47\% crude protein, $4 \%$ crude lipids for group 2 feed.

\section{Data collection}

Fish stocked in aquariums were observed for breeding intervals, fecundity and physical parameters of the laid eggs. Laid eggs per female fish were counted, recorded and compared between groups. An olympus BX51 microscope in Biotechnology Laboratory, Istanbul University Faculty of Aquatic Sciences was used for the measurements of physcial parameters of the eggs.

\section{Results and Discussions}

Fecundity

Females in group $1 \mathrm{a}$ and $1 \mathrm{~b}$ laid eggs twice during the experimental period whereas Group 2a and $2 \mathrm{~b}$ only laid one batch of eggs (Table 1). Protein rich feeds proved to sustain the broodstock for a second batch of eggs in the given experimental time period as well as creating more eggs per batch. Dahlgren [16] reported similar results on Poecilia reticulata females fed with higher ratios of protein rich diets where fish produced more eggs compared to those fed with low protein diets. Ingale and Charjan [17] concluded that increased protein content in diets resulted in noticeable higher individual fecundity especially in females. Our findings are similar with both studies where fecundity of individual females were higher with comperatively high protein diets. According to James and Sampath [18], low dietery proteins reduced egg production in B. Splendens, yet egg hatchability was not adversely affected. They concluded that if female fish were to receive sufficient proteins in their diet, continious and viable egg production and larval availibility would be possible. Our findings concur with this statement that if rainbow cichlids are supplied with adequate amounts of proteins in their diets, it is possible to continuously obtain eggs where as low proteins hinders egg production.

\section{Physical Parameters}

Luquet and Watanabe [19] suggests that better fed fish grows faster and contains significantly more but smaller eggs. In our 
study we have concluded that the amount of eggs laid decreased with the amount of proteins in the diet. Yet, the mean measured sizes of the eggs decreased with the increasing number of eggs. Mean values of egg sizes in terms of length and width are given for high protein fed groups and low protein fed groups pooled together (Figure 1 and 2).

\begin{tabular}{|l|c|c|}
\hline & 1. Batch & 2. Batch \\
\hline Group 1a & 1019 eggs (Day 17) & 985 eggs (Day 45) \\
\hline Group 1b & 1005 eggs (Day 20) & 1021 eggs (Day 42) \\
\hline Group 2a & 704 eggs (Day 15) & - \\
\hline Group 2b & 680 eggs (Day 18) & - \\
\hline
\end{tabular}

Table 1: Fecundity and batch intervals during experimental period.

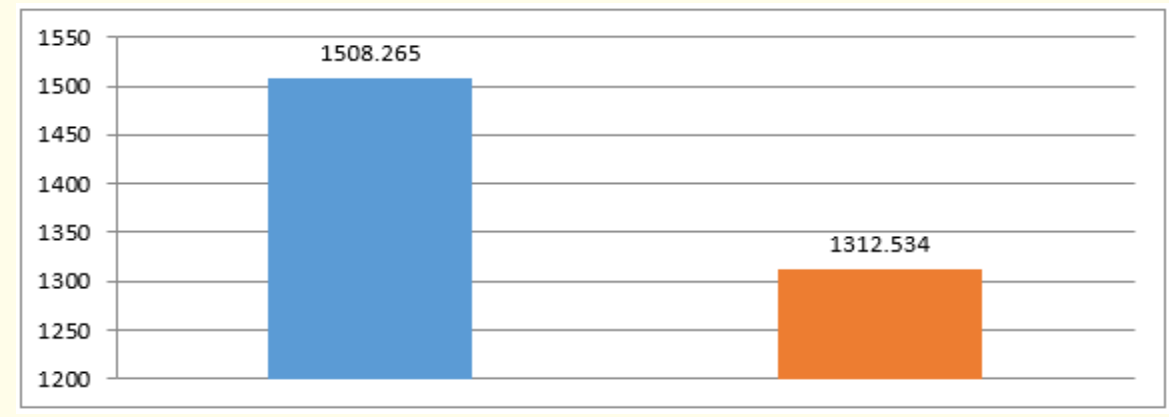

Figure 1: Egg length measurements for high protein fed groups (Blue) and low protein fed groups (Red) $(\mu \mathrm{m})$

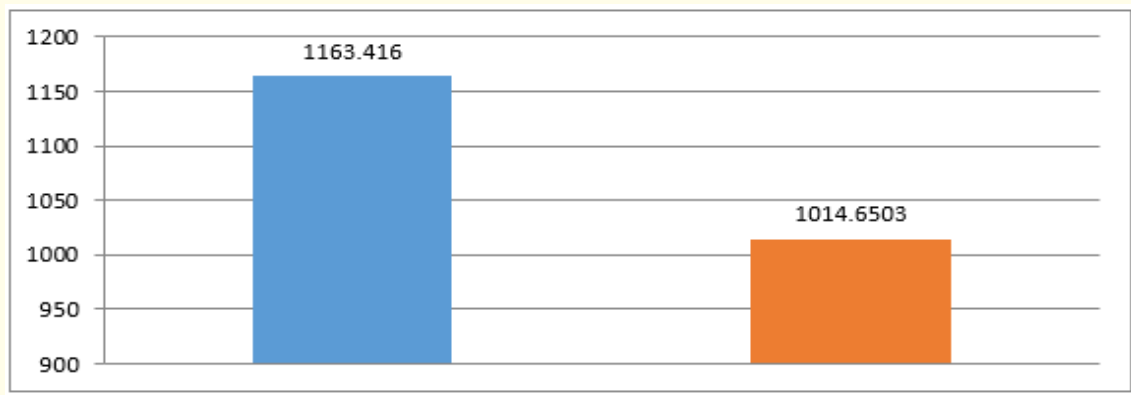

Figure 2: EEgg width measurements for high protein fed groups (Blue) and low protein fed groups (Red) ( $\mu \mathrm{m})$

\section{Conclusion}

Our results indicates that with higher protein inclusion in their diets, rainbow cichlid (Herotilapia multispinosa) tends to lay more eggs compared to low protein diets. Low protein diets had bigger eggs yet fertilization and survival performance of these eggs should be compared with the eggs laid after high protein fed broodstock as well. As the main advantage for an aquaculture producer the amount of eggs laid by the broodstock is really important it is possible to suggest high protein diets during broodstock feeding. But as mentioned before, survival and fertilization performance of these eggs should be evaluated for accurate production optimization.

\section{Bibliography}

1. Nelson JS. "Fishes of the world ( $4^{\text {th }}$ edition)". John Wiley and Sons, Inc., Hoboken, New Jersey (2006).

2. Gullu K., et al. "Optimal dietary protein levels in juvenile electric blue cichlid (Sciaenochromis fryeri)". Israeli Journal of Aquaculture - Bamidgeh 60.4 (2008): 261-267.

3. Sugie A., et al. "The evolution of genes for pigmentation in African cichlid fishes". Gene 343.2 (2004): 337-346.

4. Türkmen G and Alpbaz A. “Türkiye'ye Ithal Edilen Akvaryum Balıkları ve Sonuçları Üzerine Araştırmalar”. Ege Journal of Fisheries and Aquatic Sciences 18.3-4 (2001): 483-493. 
5. Toledo-Solís FJ., et al. "Partial characterization of digestive proteases of the three-spot cichlid Cichlasoma trimaculatum (Günter 1867)". Aquaculture Nutrition 22.6 (2016): 12301238.

6. Baylis BJR. "The Behavior and Ecology of Herotilapia multispinosa deserves more study". Ethology 34.2 (1974): 115-146.

7. Baerends GP and Baerends-Van Roon JM. "An introduction to the study of the ethology of cichlid fishes". Behaviour 1 (1950): $1-243$.

8. Courtenay SC and Keenleyside MHA. "Wriggler-Hanging - a Response to Hypoxia by Brood-Rearing Herotilapia-Multispinosa (Teleostei, Cichlidae)". Behaviour 85.3-4 (1983): 183-197.

9. Kodric-Brown A. "Sexual Dichromatism and Temporary Color Changes in the Reproduction of Fishes". American Zoologist 38.1 (1998): 70-81.

10. Seehausen 0., et al. "Cichlid fish diversity threatened by eutrophication that curbs sexual selection". Science 277.5333 (1997): 1808-1811.

11. Knight ME and Turner GF. "Reproductive isolation among closely related Lake Malawi cichlids: Can males recognize conspecific females by visual cues?" Animal Behaviour 58.4 (1999): 761-768.

12. Vavrek MA and Brown GE. "Threat-sensitive responses to disturbance cues in juvenile convict cichlids and rainbow trout". Annales Zoologici Fennici 46.3 (2009): 171-180.

13. Brown GE., et al. "Production of chemical alarm cues in convict cichlids: the effects of diet, body condition and ontogeny". Annales Zoologici Fennici 41 (2004): 487-499.

14. Wagner CE., et al. "Diet predicts intestine length in Lake Tanganyika's cichlid fishes". Functional Ecology 23.6 (2009): 11221131.

15. Reebs SG and Colgan PW. "Nocturnal care of eggs and circadian rhythms of fanning activity in two normally diurnal cichlid fishes, Cichlasoma nigrofasciatum and Herotilapia multispinosa". Animal Behaviour 41.2 (1991): 303-311.

16. Dahlgren BT. "Impact of Different Dietary-Protein Contents on Fecundity and Fertility in the Female Guppy, Poecilia-Reticulata (Peters)". Biology of Reproduction 24.4 (1981): 734-746.

17. Ingale DS and Charjan AP. "Impact of artificial and natural food on the length, weight and fecundity of Poecillia reticulata". Bioscience Biotechnology Research Communications 3.2 (2010): 195-199.

18. James R and Sampath K. "Effect of animal and plant protein diets on growth and fecundity in ornamental fish, betta splendens (regan)". The Israeli Journal of Aquaculture - Bamidgeh 55.1 (2003): 39-52.
19. Luquet $P$ and Watanabe T. "Interaction "nutrition-reproduction" in fish". Fish Physiology and Biochemistry 2.1-4 (1986): 121-129.

Volume 2 Issue 8 August 2018

(C) All rights are reserved by Deniz $D$ Tosun and

Emrah Kaya. 